Global Journal of Human Resource Management

Vol.8, No.1, pp.62-71, February 2020

Published by $E C R T D-U K$

Print ISSN: 2053-5686(Print), Online ISSN: 2053-5694(Online)

\title{
MANAGING WITH HUMOR IN THE 21ST CENTURY: DANGERS AND GAINS
}

\author{
Wobodo, Chinonye Chris ${ }^{1}$ \\ Department of Management, Faculty of Management Sciences \\ Rivers State University, Port Harcourt \\ Email:chinonyewobodo@gmail.com \\ Dr. Don-Baridam, Letam Queen ${ }^{2}$ \\ Department of Management, Faculty of Management Sciences \\ Rivers State University, Port Harcourt \\ Email: letambaridam@gmail.com
}

\begin{abstract}
This paper theoretically explored the concept of managerial humor in relation to the dangers and gains it brings into the organization as managers strive to manage the 21 st century workforce toward sustainable organizational performance. In the cause of extant literature review, four managerial humorous behavior i.e. affliative, self-enhancement, aggressive and selfdefeating were adopted as the most reliable indicators of humor practices in modern business management. Consequently, our findings revealed that managerial humorous behavior at the workplace is a phenomenon characterized by mixed effect. This is to say that each humorous disposition put up by managers leave the organization with a given consequence, which may be positive (gains) or negative (dangers) in nature. The study further discovered that managerial humor such as affiliative and self-enhancement is positive and beneficial to the organization through improved leader-member relations, while humorous behavior such as aggressive and selfdefeating are negative and detrimental to group cohesiveness due to its demeaning and abusive character. Thus, we conclude that irrespective of the obvious dark side of managerial humor, when managers effectively adopt and apply the right humor in the right context, it create a platform for improved employee well-being and other organizational outcomes such engagement and commitment. Thus, we recommend as follows: $i$ ) that manager should always make use of positive humor as a means of communicating information that may be considered offensive to the employees. ii) that managers in order to keep their interpersonal relationships with followers on track should try as much as possible to avoid the use of negative humorous jokes.
\end{abstract}

KEYWORDS: managerial humor, affiliative humor, self-enhancing humor, aggressive humor, self-defeating humor, dangers, gains

\section{INTRODUCTION}

Every organization is considered teleologic in character be it big or small, public or private. Buttressing this further, Drucker and Maciariello (2008) argue that among the several goals organizations are set out to achieve, the goal of value creation remains the most critical. Others may include profitability, growth and expansion, good corporate citizenship behavior, goodwill, 
Global Journal of Human Resource Management

Vol.8, No.1, pp.62-71, February 2020

Published by ECRTD-UK

Print ISSN: 2053-5686(Print), Online ISSN: 2053-5694(Online)

survival (Jaja, Gabriel \& Wobodo, 2019), and sustainability. However, the extent to which these goals are pursued and actualized is mainly tied to the quality of management team the organization has on ground. This is because an ineffective management team could lead the organization into its early entropy even when every other organization's resource such as material, machine, money and human capital are well situated. Their actions and inactions leave the organization with a given consequence, which is either positive or negative. This follows Wang, Huang and Chen (2011) argument that in every organization, the most essential and influential individuals are the managers. In the same manner, Frost (2017) maintains that the role managers' play in the workplace is perhaps the most significant due to their impact on organizational performance.

Consequently, managers in a bid to ensure their actions and inactions yield positive impact on the employees and the organization in general exhibit different leadership behaviors such as autocratic, democratic, Laissez-faire, humorous behavior etc. For instance, Hiller, DeChurch, Murase and Doty (2011), stated that managers of organization engage in behaviors at the workplace that are intended to swayed the employees' actions. These behaviors may either be perceived as positive or negative by the employees thereby leading to a dissimilar response or result. This is as a positive managerial behavior has been observed to spur the employees toward engagement and commitment, while the reverse is usually the case when managers exhibit negative behaviors, and this often manifests through the display of all forms of deviant work behaviors such as recurrent incidence of dysfunctional conflict, goal sabotage, absenteeism, stealing, information hoarding etc. No wonder, Obiwuru, Okwu, Akpa and Nwankwere (2011) stressed that a leader's behavior is one factor that plays significant role in enhancing or retarding the interest and commitment of the employees in the organization. Thus, Yam, Christian, Wei, Liao and Nai (2018) assert that in today's contemporary business management, successful leader-managers now use their sense of humor to win followers' support, motivate their followers, and even create lasting memories for the world around them. A view which also corroborates Avolio, Bass and Jung (1999) earlier observation that managerial humor is an essential trait and competency of leaders.

It is on this premise that the adoption and application of managerial sense of humor in managing organization is considered a critical ingredient for leadership effectiveness and 21st century workforce optimal utilization. This is because as managers, besides being responsible for the sustainability of the organization, they are also charged with the task of leading the whole organizational members, and ensuring effective and efficient performance at all levels by ensuring their wellbeing. Accordingly, Mesmer-Magnus and Glew (2012) revealed that the benefits of managerial sense of humor in the advancement of employees' general well-being have long been observed. In furtherance, Goswami et al. (2016) allude that managers' humorous behavior can make their subordinates experience positive emotions which results to employee engagement. Thus, given credence to Wang, Huang and Chen (2011) earlier position that to succeed at all levels, managers must develop a good interactive behavior such as humor to facilitate cooperation and open communications with and among members which in the long run leads to goal attainment. Similarly, Messmer (2006) maintains that managers who apply positive sense of humor in day-today interaction are perceived favorably by their employees.

However, amid the positive contributions and gains that managerial humorous behavior has been credited with by several scholars, it is also important to note that some other studies have raised 
Global Journal of Human Resource Management

Vol.8, No.1, pp.62-71, February 2020

Published by ECRTD-UK

Print ISSN: 2053-5686(Print), Online ISSN: 2053-5694(Online)

alarm that some unguarded managerial humorous behavior may pose a serious danger to organizational attainment. This is as Malone (1980) pointed out that humor can be likened to a double-edged sword which is characterized by good and bad side; meaning that some humorous behavior can be both physically and mentally destructive if not appropriately applied. In consonance with this observation, Wang et al. (2011) argued that the extent to which managers' sense of humor affect organizational performance is dependent on how managers are able to successfully apply humor as well as how the humor applied fits with the traits of the individuals within the organization. While, Yam et al. (2018) also in their recent study reechoed that managers' sense of humor can be a mixed blessing and elicit unforeseen negative behaviors from their followers.

Despite this observed multidimensionality, there is still a lack of theoretical evidence that clearly demonstrates the dangers and gains associated with the application of managerial sense of humor in the management of 21st century workforce. Mesmer- Magnus and Viswesvaran (2012) also observed this lacuna when they argued that there is little shared understanding as to the role of humor in the workplace. Though we have come across several studies in this direction such as Abel (2002) whose study focused on humor, stress, and coping strategies; Billig (2005) looked at it from the perspective of laughter and ridicule towards a social critique of humor; Bressler and Balshine (2006) examined the influence of humor on desirability; Chen and Martin (2007) examined a comparison of humor styles, coping humor, and mental health between Chinese and Canadian university students; Gkorezis, Petridou and Xanthiakos (2014) investigated leader positive humor and organizational cynicism using LMX as a mediator, while Valeria (2019) assessed the interplay between humor and identity construct. Observably, all these studies only tried to establish the influence of humor on organizational outcome using different variables without specific attention to its dangers and gains in relation to workforce management. Based on this lacuna, this paper theoretically explores the concept of managerial humor behavior through the lens of its dangers and gains in managing the 21 st century workforce within the context of Nigeria business milieu.

\section{The Meaning and Nature of Managerial Humor}

Humor is a highly contextualized subject matter which has the capacity to produce unplanned workplace outcomes that affect the emotional state of people concerned. It is a common and important aspect of organizational interactions (Kim \& Plester, 2019). Martin (2001) refers managerial humor as trait-like individual tendency to display behaviors, attitudes, and capabilities relating to amusement during social interactions. For Romero and Cruthirds (2006), it as an amusing communication that brings about positive emotions and cognitions in the individuals, groups and organizations. Similarly, Lang and Lee (2010) regarded it as an indirect and uncertain form of communication related to body gestures and facial expressions composing the tacit knowledge common to the people involved. While Robert and Yan (2007), view it as a deliberate form of social communication presented by a producer (manager) toward his (audience) followers. Plester (2016) on the other hand added that it is a complex social interaction that may incorporate feelings of amusement or can evoke laughter, but may also have unexpected or unpleasant implications. Drawing from these definitions, we refer managerial humor as a comic driven communication behavior geared toward elevating stress and tension in the minds of the employee. 
Global Journal of Human Resource Management

Vol.8, No.1, pp.62-71, February 2020

Published by $E C R T D-U K$

Print ISSN: 2053-5686(Print), Online ISSN: 2053-5694(Online)

Humor is usually intentional in nature with the hope of creating an atmosphere for sustainable group cohesion and improved performance. This view can also be seen in Romero and Cruthirds (2006), wherein they succinctly observed that the concept of humor is an indispensible element in building effective interpersonal relationships.

Accordingly, Conger (1989) earlier observation on the impact of managerial humor at the workplace indicates that managers' continuous adoption of humorous behaviors at the workplace creates an atmosphere for enhanced employee inspiration and improved morale. In the same vein, Fox and Amichai-Hamburger (2001) indicate that managerial humor is critically emphasized at the workplace because of its constructive effects on promoting organizational change, while Romero and Pescosolido (2008) see it as a strong tool for improved group effectiveness. In fact, Craumer (2002) argued that through the application of appropriate humorous behaviors, managers could help employees get along with one another, thereby promoting peer interaction and love. Yet, another argument that support the use of managerial humor at the workplace is the fact that today's workforce group such as the generation Yers (those in the organization born between the years 1981 to 2000) and generation Zers (these are exceptional workforce born in the year 2000), who feel that a balanced work-life is about proper blend of both work and personal life in such a manner that leisure and work is achieved at the same time. In synergy with this view, Levine (2005) stated that 18 - 25 years old persons at the workplace are inclined to work in a happy environment. While, Wiltham (2007) notes that such younger workforce places higher importance on a workplace culture that is, tension free, fun driven, and positive.

\section{Taxonomies of Managerial Humor}

Studies show that managerial humor is a multidimensional construct. For example; Svebak (1974) in his study identified three elements of humor as including sensitivity to humor, attitudes toward humor and expression of humor. Martin, Puhlik-Doris, Larsen, Gray and Weir (2003) developed four managerial humorous behaviors as affiliative humor, self-enhancing humor, aggressive humor and self-defeating humor. Another approach to examining humor is through looking at its effect, whether it is positive or negative (Samson \& Gross, 2012). However, in this study we considered Romero and Cruthirds (2006) conceptualization more appropriate for our use since it captures both positive and negative humors that can be used to offer explanation on its gains and dangers in managing 21 st century workforces.

\section{Affiliative Humor}

According to Miczo and Welter (2006), affiliative humor refers to joke that is intended to produce laughter and other forms of amusement in targets. Additionally, Wang et al. (2011) view it as a spontaneous jocose and a type of non-hostile humor. Based on this, we view affiliative humor as a positive managerial behavior (jokes) intended to instill positive emotion in others to promote and strengthen interpersonal relationships. This align with Thelen (2018) assertion that managers who score high on affiliative humor say funny things, engage in funny stories to bring people together, reduce tension, and put others at ease. This type humorous behavior not only create a fun-work environment, it also create a platform that enhances employee retention; especially, the gen Yers and Zers cohorts whose most preferred work environment is a mixture of work and leisure ( Tamunomiebi \& Wobodo, 2018). And in their character as pointed out in Levine (2005) will likely 
Global Journal of Human Resource Management

Vol.8, No.1, pp.62-71, February 2020

Published by $E C R T D-U K$

Print ISSN: 2053-5686(Print), Online ISSN: 2053-5694(Online)

ditch boring organizations for a fun driven one. This is why in organizations today managers adopt affiliative humorous behavior as a reliable motivational instrument for a sustainable managerfollowers interpersonal cohesion. Thus, easing out interpersonal strangeness and nervousness and instill enthusiasm into social occasions (Wang et al, 2011).

\section{Self-enhancing Humor}

This type of humorous behavior is individualistic in nature, though a positive one. It is associated with managers' humorous behavior towards self in order to adequately adapt to challenging circumstances that characterize the workplace such as Nigeria. Thus, Freud et al. (1991) maintain that humor is one of the most effective forms of coping with life stresses. This is evident in Yaozhong and Wang (2016) wherein they refer self-enhancing humor managers as individuals with an optimistic attitude towards life, who are not usually frustrated in the face of inevitable sufferings. As such, when they go through adversity, they develop resilient attitude and reconfigure themselves through humorous activities. This also justifies Martin et al. (2003) position that selfenhancing humor emphasizes more on internal reconfiguration of oneself. Thus, such reconfiguration may manifests in the form of a progressive adaptive capacity building amid different stress and other unabated challenges that manager face on daily basis. Adaptability is associated with managers' ability to expect and respond to threats and latent opportunities by influencing the situation to his advantage (Cohen and Levinthal, 1990), which means that behavior such as self-enhancing humor serves as a self-protective gadget when faced with perturbation. Or a responsive defense mechanism in the face stress (Wang et al., 2011).

\section{Aggressive Humor}

In the organization when managers engage in aggressive humorous behavior, they do so with the intension to undermine the ego of their subordinates, while glorifying theirs. Thus, making it a negative phenomenon and destructive in character, especially as it brings about a dysfunctional state of interpersonal relations among group. This is why Kim and Plester (2019) assert that it is a form of negative humor adopted to control others by putting them down through ridicule. Similarly, Wang et al. (2011) stressed that such humor comes with ridicule, sarcasm and jeer which is usually perceived as derogatory by the listeners. Aggressive humor is manipulative and oppressive in nature which is why its potential impact on subordinates may pose a serious threat on industrial harmony. Aggressive humorous behavior may be likened to ethnocentric behavior which an individual displays in a group just to relegate the self-esteem of others, while claiming superiority over them. In fact, such individuals are best described as class conscious fellows. This is because they go extra mile to arrogate undue influence to themselves in order to continuously boost their ego over and above reality. Wang et al. (2011) further clarify this context as they pointed out that the adoption of aggressive humor in an organization is mainly to manipulate or order team members through one's sense of superiority.

\section{Self-Defeating Humor}

This type of humor may be regarded as an unhealthy and negative humorous behavior displayed against oneself in order to enhance relationship with others. In fact, it is self-relegation prone. Accordingly, Martin et al. (2003) refers it as humorous behavior designed to put others at ease by showing that the producer (manager) does not take himself or herself too seriously. Additionally, Unal (2014) posits that such humorous action is a self-denying defense mechanism that tends to 
Global Journal of Human Resource Management

Vol.8, No.1, pp.62-71, February 2020

Published by ECRTD-UK

Print ISSN: 2053-5686(Print), Online ISSN: 2053-5694(Online)

hide negative feelings away from problems through humor. Consequently, we may allude that a manager whose humorous behavior is built on self-defeating may end up ruining his leadership credibility before his followers or subordinates. For instance, Zillmann and Stocking (1976) as cited in Wang et al. (2011) confirmed this view when they stated that that when managers display this form of humor, it may undermine the confidence subordinates reposed on them. This is because with such a self- inflicted inferiority complex, followers or subordinates may begin to perceive the manager as incompetent and unserious even when issues of urgent importance are being discussed.

\section{Dangers of Managers' Humorous Behavior}

As essential as managerial humorous behavior in creating a fun-based work environment, it is also evident that not all humorous behavior that managers display is healthy for organizational success. For instance, Decker, Yao, and Calo (2011) in their study noted that not all humor can have a positive effect, while Kauffeld and Lehmann (2012) reinforced same position by stating that sarcastic jokes tend to gravely affect the efficiency of organization. This is as negative humorous behavior such as aggressive and self-defeating rather than create bond between managers and subordinate situate disaffection and disharmony between them, because of its abusive and demeaning nature; thereby causing a serious crack on leader-subordinate relationships. Teo (2019) affirms that humor such as aggressive joke is detrimental to employees' creativity, and causes dysfunctional resistance in teams and organizations (Romero \& Cruthirds (2006). In the same vein, Ruch, Heintz, Platt, Wagner and Proyer (2018) established that dark (negative) humorous behavior such as mockery, cynicism and sarcasm relate to lower psychological well-being. Further studies prove that managers who use aggressive and particularly, self-deprecating types of humor are more likely to report higher levels of anxiety, depression and negative self-judgments, and lower levels of self-esteem and security in attachments (self-focused maladaptive humor, Kuiper, Grimshaw, Leite and Kirsh (2004); hostile and self-defeating humor, Saroglou and Scariot, 2002).

\section{Gains of Managers' Humorous Behavior}

As stated earlier, managers in a bid to achieve organizational set out goals adopt different leadership behaviors and strategies to continuously get the employees committed and engaged. And in the forgoing paragraphs, we have established that one of such behaviors that mangers exhibit is humorous behavior at different context. Thus, in this section we are poised to assess the gains or benefits that these behaviors have to offer in stimulating the 21 st century workforce in Nigeria toward sustained performance. Leaning on available empirical and theoretical evidence, positive managerial humor could be used to create a collegial work environment that triggers industrial harmony, which is considered as a state of relative peace and cordiality, characterized by trust, unity of purpose and an absence of discontent in organizational relationships (Akume \& Abdullahi, 2013). Thus, reinforcing the position of Holmes (2006) wherein the study found that positive humor at the workplace enhances team cohesion through increase harmonious relationship among group. Furthermore, Susa (2002) reveals that humor is associated with higher organizational commitment. This is so because, when an organization is characterized by harmonious interpersonal relationships as a result of managers' affiliative and self- enhancing humorous disposition, the organization is bound to witness group cohesiveness. Especially, as managers with such humorous behaviors is considered fun and enjoyable to work with. 
Global Journal of Human Resource Management

Vol.8, No.1, pp.62-71, February 2020

Published by ECRTD-UK

Print ISSN: 2053-5686(Print), Online ISSN: 2053-5694(Online)

Managers' humorous disposition can help the subordinate fight and overcome work and family stressors which may threaten commitment and performance. Accordingly, Abel (2002) observed that managerial humor may reduce burnout by helping employees deal with difficult situations, release tension, regain perspective on their jobs, and facilitate an optimistic reinterpretation of events. Similarly, Samson and Gross (2012) added that humor can be a stress reducer and morale booster. Wang et al. (2011) in their study discovered that humorous behavior such as selfenhancing humor can directly and positively enhance leaders' innovative behavior and their leadership effectiveness. Holmes (2007) in her study found that in group brainstorming and meetings, the use of humor facilitates creative thinking and innovative idea generation, while at the same time stabilizing workplace relationships. This therefore supports Romero and Cruthirds (2006) findings that positive forms of humor, especially affiliative humor, can act as a social lubricant that instills good feelings which bond managers and subordinates together. Banking on this, Dikkers, Doosje, and de Lange (2012) assert that managerial humor is of significant consequence to business, especially in leading the $21^{\text {st }}$ century workforce in developing nation like Nigeria.

\section{CONCLUSION AND RECOMMENDATIONS}

This study basically reviewed the meaning and nature of managerial humor in relation to its gains and dangers in managing $21^{\text {st }}$ century workforce. In the cause of literature exploration, the study adopted affiliative, self-enhancement, aggressive and self-defeating humor as the taxonomies of managerial humor. Consequently, extensive literature review revealed that managerial humorous behavior at the workplace is a phenomenon characterized by mixed effect. This is to say that each humorous disposition put up by managers leaves the organization with a given consequence, which may be positive (gains) or negative (dangers) in nature. The study further discovered that managerial humor such as affiliative and self-enhancement is positive and beneficial to the organization through improved leader-member relations, while humorous behavior such as aggressive and self-defeating are negative and detrimental to group cohesiveness due to its demeaning and abusive character. Thus, we conclude that irrespective of the obvious dark side of managerial humor, when managers effectively adopt and apply the right humor in the right context, it create a platform form for improved employee well-being and other organizational outcome such engagement and commitment. Thus we recommend as follows:

i) That manager should always make use of positive humor as a means of communicating information that may be considered offensive to the employees.

ii) That manager in order to keep their interpersonal relationships with follower on track should try as much as possible to avoid the use of negative humorous jokes.

\section{Contribution to Knowledge}

Studies such as Mesmer-Magnus and Viswesvaran (2012) and others as identified in this study has shown that there is a lack of theoretical evidence that demonstrates the dangers/gains associated with the use of managerial sense of humor in the management of $21^{\text {st }}$ century workforce. This study has contributed greatly to the development of literature on this subject by exploring the concept of managerial humor in relation to the dangers/gains it brings into the organization. By 
Global Journal of Human Resource Management

Vol.8, No.1, pp.62-71, February 2020

Published by $E C R T D-U K$

Print ISSN: 2053-5686(Print), Online ISSN: 2053-5694(Online)

lending credence to the various humor styles discussed in the paper, the study has helped managers to have a clear understanding on the various humor styles. This can help them to adopt the right humor style suitable for the desired organizational outcome. For instance, they could increase their effectiveness through the judicious use of healthy humorous behavior. On the other hand, avoid unhealthy behaviors which could be detrimental to the organization.

\section{References}

Abel, M. H. (2002). Humor, stress, and coping strategies. International Journal of Humor Research, 15(2), 365-381

Akume, A., \& Abdullahi, Y. (2013). Challenges and prospects of effectives industrial conflict resolution in Nigeria. Journal of Social Sciences, 36(2), 119-208.

Avolio BJ, Bass BM, Jung DI (1999). Re-examining the components of transformational and transactional leadership using the multifactor leadership questionnaire. Journal of Occupational Organization of Psychology, 72(2), 441-462

Billig, M. (2005). Laughter and ridicule: Towards a social critique of humor. London: Sage Publications.

Bressler, E. R., \& Balshine, S. (2006). The influence of humor on desirability. Evolution and Human Behavior, 27(3), 29-39.

Chen, G. H., \& Martin, R. A. (2007). A comparison of humor styles, coping humor, and mental health between Chinese and Canadian university students. Humor: International Journal of Humor Research, 20(2): 215-234.

Conger, J. A. (1989). The charismatic leader: Beyond the mystique of exceptional leadership. San Francisco, CA: Jossey-Bass.

Craumer, M. (2002). Getting serious about workplace humor. Harvard Management. Communication News. 2(1), 3-4.

Decker, W. H., Yao, H., \& Calo, T. J. (2011). Humor, gender, and perceived leader effectiveness in China. SAM Advanced Management Journal, 76(1), 43

Dikkers, J., Doosje, S., \& de Lange, A. (2012). Humor as a human resource tool in organizations. In J. Houdmont, S. Leka, \& R. R. Sinclair (Eds.), Contemporary occupational health psychology: Global perspectives on research and practice. Hoboken, New Jersey: WileyBlackwell, 2(2) 74-91.

Drucker, P., \& Maciariello, J. A. (2008). Management. Rev. Ed.: New York: Harper Collins Publishers.

Freud, S., Strachey, J., \& Richards, A. (1991). Jokes and their relation to the unconscious. London: Penguin Book.

Gkorezis, P., Petridou, E., \& Xanthiakos, P. (2014). Leader positive humor and organizational cynicism, LMX as a mediator Leadership \& Organization Development Journal, 35 4), 305-315

Goswami, A., Nair, P., Beehr, T., \& Grossenbacher, M. (2016). The relationship of leaders' humor and employees' work engagement mediated by positive emotions: Moderating effect of leaders' transformational leadership style. Leadership \& Organization Development Journal, 37(8), 1-19.

Hiller, N. J., DeChurch, L. A., Murase, T., \& Doty, D. (2011). Searching for outcomes of leadership: “A 25-year review”, Journal of Management, 37(4), 1137-1177. 
Global Journal of Human Resource Management

Vol.8, No.1, pp.62-71, February 2020

Published by $E C R T D-U K$

Print ISSN: 2053-5686(Print), Online ISSN: 2053-5694(Online)

Holmes, J. (2006). Sharing a laugh: Pragmatic aspects of humor and gender in the workplace, Journal of Pragmatics, 38(1), 26-50.

Jaja, S. A., Gabriel, J. M. O., \& Wobodo, C. C. (2019). Organizational isomorphism: The quest for survival. Noble International Journal of Business and Management Research, 3(5), 8694.

Kauffeld, S., \& Lehmann-Willenbrock, N. (2012). Meetings matter effects of team meetings on team and organizational success. Small group research, 43(1)130-158.

Kim, H. S., \& Plester, B.A. (2019). Harmony and distress: humor, culture, and psychological wellbeing in south korean organizations. US National Library of Medicine National Institutes of Health.

Malone PB (1980). Humor: A double-edged tool for today's managers? Academy Management. Review., 5(3), 357-360.

Mesmer-Magnus, J., \& Glew, D.J. (2012). A meta-analysis of positive humor in the workplace. Journal of Managerial Psychology, 27(2), 155-190

Messmer, M. (2006). Human resources kit for dummies, John Wiley \& Sons, Chichester

Miczo, N., \& Welter, R.E. (2006) . Aggressive and affiliative humor: Relationships to aspects of intercultural communication. Journal of Intercultural Communication Research, 35(1), 2006, 61-77.

Obiwuru, T., Okwu. A,. Akpa. V., \& Nwankere, I. (2011). Effects of leadership style on organiszational performance: A survey of selected small scale enterprises in Ikosi -Ketu Council development area of Lagos State, Nigeria. Australian Journal of Business and Management Research, 1(7), 25-34.

Pester, B. A. (2016). The complexity of workplace humour. laughter, jokers, and the dark side of Humour. London: Springer

Ruch, W., Heintz, S., Platt, T., Wagner, L., Proyer, R. T. (2018a). Broadening humor: Comic styles differentially tap into temperament, character, and ability. Front. Psychol. 9(6), 410.

Samson, A., \& Gross, J. (2012). Humor as emotion regulation: The differential consequences of negative versus positive humor. Cognition \& Emotion, 26(2), 375-84

Susa, A. M. (2002). Humor type, organizational climate, and outcomes: The shortest distance between an organization's environment and the bottom line is laughter", Dissertation Abstracts International, 63(1), 6131.

Teo, S. (2019). Jokes in the office are no laughing matter. https://www.ecu.edu.au/news/latestnews/2019/06/jokes-in-the-office-are-no-laughing-matter

Thelen, P. (2018). The impact of humor styles in the workplace https://instituteforpr.org/theimpact-of-humor-styles-in-the-workplace/

Tamunomiebi , M.D. \& Wobodo, C.C. (2018). The changing trends in workers demographics: A review of X, Y, and Z generations in the corporate world. Global Scientific Journal 6(10).

Ünal, Z. M. (2014). Influence of leaders' humor styles on the employees' job related affective well-being .International Journal of Academic Research in Accounting, Finance and Management Sciences, 4(1), 201-211.

Valeria. S. (2019). The interplay between humor and identity construction: From humorous identities to identities constructed through humorous practices. Journal of Pragmatics 152(3), 127-131. 
Global Journal of Human Resource Management

Vol.8, No.1, pp.62-71, February 2020

Published by ECRTD-UK

Print ISSN: 2053-5686(Print), Online ISSN: 2053-5694(Online)

Wang, L.Y., Huang, H. \& Chen, H. (2011). Influence of humorous leadership at workplace on the innovative behavior of leaders and their leadership effectiveness. African Journal of Business Management. 5(16), 6674-6683.

Yam, K. C., Christian, M. S., Wei, W., Liao, Z., \& Nai, J. (2018). The mixed blessing of leader sense of humor: Examining costs and benefits. (2018). Research Collection Lee Kong Chian School of Business. Academy of Management Journal. 61, (1), 348-369. 